\title{
The Role of Counsel in the Civil Commitment Process: A Theoretical Framework
}

\author{
The last two decades have witnessed a careful reexamination of the \\ rights due to persons subject to the civil commitment process. ${ }^{1}$ Not \\ unexpectedly, most states now provide for counsel to represent the \\ respondent to a commitment petition at the hearing," thereby heeding
}

1. "Civil commitment" refers here to any state-imposed involuntary detention or restriction on personal liberty based on a person's being deemed mentally ill. In 1972 , 169,032 persons, or 41.8 percent of the 403,924 persons admitted to state and county mental hospitals, were involuntarily committed. Developments in the Law-Civil Commitment of the Mentally Ill, 87 HARV. L. REV. 1190,1193 n.3 (1974).

The commitment of youths pursuant to juvenile court adjudications traditionally falls under the rubric of civil commitment. While juvenile court proceedings and commitment proceedings for the mentally ill share much in common, see note 20 infra, this Note focuses only on the proper role for counsel in the civil commitment of the mentally ill. Therefore, unless otherwise qualified, "civil commitment" here refers only to the commitment of the mentally ill.

Procedures by which one is civilly committed vary greatly from state to state, rendering description of a "typical" civil commitment procedure impossible. Most jurisdictions, however, provide for both emergency and non-emergency detentions. Emergency detentions are undertaken with minimal procedural safeguards, being premised on the belief that the individual sought to be detained is imminently dangerous to himself or others. The duration of such detentions varies among jurisdictions. Compare D.C. CODE ANN. $\$ 21-523$ (1973) (48 hours) with CONN. GEN. STAT. REv. \$17-183 (1973) (15 days).

Non-emergency commitment proceedings are generally initiated either where the individual is already hospitalized and is seeking release (through, for example, habeas corpus proceedings, revocation of a voluntary commitment, or expiration of the emergency detention period) or when the individual is felt to be in need of hospitalization, though not immediately.

Who may initiate commitment proceedings also varies among states. In Washington, for example, emergency detention may be initiated only by either a mental health professional or a police officer. WASH. REv. CODE ANN. $\$ 71.05 .150$ (Supp. 1974). Connecticut, in contrast, permits emergency detention only upon a physician's certification that such detention is necessary. CoNN. GEN. STAT. REv. $\$ 17-183$ (1973). Fewer restrictions generally are placed on who is eligible to petition for non-emergency commitment proceedings. See, e.g., Conn. Gen. Stat. Rev. $\$ \$ 17-177,17-178$ (1973); WASH. REv. CODE ANN. $\$ 71.05 .160$ (Supp. 1974).

Hearings show great disparity, both in the form of the tribunal and the degree of formality, among jurisdictions. Some states vest the decision-making power in administrative tribunals. See, e.g., IowA CODE $\$ \$ 229.1-.44$ (1971); others vest the power in courts. See, e.g., ConN. Gen. STAT. REv. \$ 17-177 (1973). Some jurisdictions provide for jury trials. Compare D.C. Code ANN. $\$ 21-545($ a) (1973) with Cons. Gen. STAT. Rev. $\$ \$ 17-176$ to 17-206k. Burdens of proof vary as well. See, e.g., In re Ballay, 482 F.2d 648 (D.C. Cir. 1973) (beyond a reasonable doubt standard); Tippett v. Maryland, 436 F.2d 1153 (4th Cir. 1971), cert. dismissed sub nom. Murel v. Baltimore City Crim. Ct., 407 U.S. 355 (1972) (preponderance standard in defective delinquency proceeding); Dixon v. Attorney General, 325 F. Supp. 966, 974 (M.D. Pa. 197I) (clear, unequivocal, and convincing standard). Frequently the complainant is unrepresented by counsel. See note 60 infra.

For a discussion of the civil commitment process, see, e.g., S. BRAKEL \& R. Rock, THE Mentally Disabled and the Law (1971); N. KitTrie, The Right to Be Diffrkent (1971); Developments in the Law, supra.

2. At present approximately 42 states and the District of Columbia provide for such representation. S. BRAKeL \& R. Rock, supra note 1, at 125-28, Table 3.12 ("Legal Counsel in Hospitalization Proceedings"). In only 23 of these jurisdictions, however, is the commiting court required to appoint counsel for an unrepresented respondent. Six others call for mandatory appointment only upon request of the respondent, while another half dozen leave such appointment upon request to the discretion of the court. Compensation 
the lesson of history that the right to counsel is the key to the continued vitality of other due process rights. ${ }^{3}$

Supreme Court rulings in two cases concerning due process requirements in juvenile court proceedings, In re Gault ${ }^{4}$ and In re Winship, ${ }^{5}$ have formed the cornerstone for the proposition that counsel is constitutionally required in civil commitment. ${ }^{6}$ In Gault the Court ruled that a child is entitled to be represented by counsel at the adjudicatory stage of a juvenile court proceeding in which the child may be found delinquent and subjected to the loss of his liberty. Winship extended the holding of Gault and required that the standard of proof be "beyond a reasonable doubt" in proceedings in which a juvenile is charged with an act which if committed by an adult would constitute a crime. Several courts have used the logic of Gault and Winship in fashioning a similar right to counsel in civil commitment proceedings. ${ }^{7}$

for counsel by the state is part of only 26 of these statutory schemes. $I d$.

Studies conducted in recent years show that the presence of counsel can dramatically affect the outcome of civil commitment hearings. Wenger and Fletcher found a marked increase in the duration of the hearings and a concomitant decrease in the rate of commitment. Wenger \& Fletcher, The Effect of Legal Counsel on Admissions to a State Mental Hospital: A Confrontation of Professions, $10 \mathrm{~J}$. OF HeAlTh \& Soctal BehavioR 66 (1969). See Lewin, Disposition of the Irresponsible: Protection Following Commitment, 66 Mich. L. REv. 721 (1968), (empirical study of the effect of counsel on the discharge of persons who had been committed following acquittals by reason of insanity).

After monitoring hearings in which representation was provided by attorneys on the staff of New York's Mental Health Information Service, Gupta concluded that the role counsel chose to assume at the hearings had an important bearing on case dispositions. Gupta, New York's Mental Health Information Service: An Experiment in Due Process, 25 RUTGERS L. Rev. 405, 437-38 (1971).

3. See, e.g., Powell v. Alabama, 287 U.S. 45, 68-69 (1932).

4. 387 U.S. 1 (1967).

5. 397 U.S. $358(1970)$.

6. For a discussion of the similarities between the two systems, see note 20 infra.

7. In re Barnard, 455 F.2d 1370 (D.C. Cir. 1971); Heryford v. Parker, 396 F.2d 393 (10th Cir. 1968); Lessard v. Schmidt, 349 F. Supp. 1078 (E.D. Wis. 1972), vacated and remanded for more specific order, 414 U.S. 473 (1974), on remand, 379 F. Supp. 1376 (1974), appeal docketed, 43 U.S.L.W. 3332 (Dec. 3, 1974) (No. 691); Dixon v. Pennsylvania, 325 F. Supp. 966 (M.D. Pa. 1971); McCorkle v. Smith, 100 N.J. Super. 595, 242 A.2d 861 (1968); People ex rel. Woodall v. Bigelow, 20 N.Y.2d 852, 231 N.E.2d 777 (1967); State v. Collman, 497 P.2d I233 (Ore. 1972); Quesnell v. State, 83 Wash. 2d 224, 517 P.2d 568 (1974); State ex rel. Hawks v. Lazaro, 202 S.E.2d 109 (W. Va. 1974). Some jurisdictions granted the right to counsel prior to Gault. See, e.g., Dooling v. Overholser, 243 F.2d 825 (D.C. Cir. 1957); State ex rel. Anderson v. United States Veterans Hosp., 268 Minn. 213,128 N.W.2d 710 (1964) (dictum).

Since Gault and Winsinip both dealt with proceedings involving the commission of an act which, if committed by an adult, would be a crime, both cases could arguably be
limited in their application to mental health proceedings in which a criminal act allegedly had occurred. Examination of the Court's rationale, however, shows that such a reading of the cases would be unduly narrow. Underlying the Court's decision were the twin effects of a juvenile commitment: the stigma that attaches to a youth's being labeled a juvenile delinquent and the resulting loss of liberty. These considerations are as relevant to a mental health commitment proceeding based upon a desire to protect the respondent from a proceeding designed to protect the public from his criminal activity. In each the respondent is threatened with the stigma of being branded mentally ill and with the burden of involuntary commitment. 
While most state legislatures and a number of courts have thus recognized the need for representation by counsel at commitment hearings, they have completely failed to recognize the need to define the role counsel is to play in these proceedings. ${ }^{8}$ Role ambiguity stems from two basic assumptions underlying the system. First, even though the respondent might say that he does not want help, his words may not express his "true" desires because he may be mentally ill (the very condition that renders him subject to the proceeding). Second, the proceeding is designed to help the respondent. ${ }^{9}$

Reasoning from this perspective, which views all the other actors in the commitment drama as benevolent figures, many feel that the lawyer should join in seeing that his client obtains the help that the client would want if only he knew what is in his own best interest. If the lawyer instead fights commitment he will at times precipitate the release of an individual who needs hospitalization and who might consequently harm himself or the community. In addition, the prospect of arguing strenuously for and gaining the release of a client who counsel believes should be treated for the client's own welfare runs counter to the humanistic values of many a lawyer. The defeat of a commitment petition directed against a client with suicidal tendencies or too old to care for himself cannot but weigh heavily on counsel's mind. Thus, many commitment lawyers take the position that counsel should oppose a commitment petition for a client only if he has determined in his own mind that the client should not be committed.10

In contrast, other commitment lawyers feel that they should assume the traditional adversary role. These lawyers resist allowing their perceptions of the client's best interests to interfere with their advocacy of the client's expressed desires, believing that their role is to advo-

8. Cases which grant the right to counsel to respondents to civil commitment petitions, see note 6 supra, fail to speak directly to the question of the role counsel is to play. On the statutes see notes 13 and 14 infra.

9. While it is analytically helpful to distinguish commitment hearings conducted for the purpose of helping an individual from those conducted for the purpose of protecting society, see p. 1549 infra, the notion that the respondent's interests are primary pervades discussions of the civil commitment process.

10. For reports of counsel acting pursuant to the best interest model, see M. Jacosson \& R. Janopaul, Hospitalization and Discharge of the Mentally Ill 165 (1968); Andalman \& Chambers, Effective Counsel for Persons Facing Civil Commitment: A Survey, a Polemic, and a Proposal, 45 Miss. L.J. 43, 59 (1974); Cohen, The Function of the Attorney and the Commitment of the Mentally Ill, 44 Texas L. Rev. 424, 445, 450 (1966); Dix, Hospitalization of the Mentally Ill in Wisconsin: A Need for Reexamination, 51 MARQ. L. REv. 1, 32 (1967); Wexler, Scoville, et al., The Administration of Psychiatric Justice: Theory and Practice in Arizona, 13 ARIz. L.R. 1, 32 (1967); Contemporary Studies Praject: Facts and Fallacies About Iowa Civil Commitment, 55 IowA L. REv. 895, 920-21 (1970); Symposium-How to Represent Clients at Mental Commitment Hearings, 23 LEGAL AiD BRIEF CASE 19, 20 (1964). 
cate, and that the decision as to commitment should be left with the factfinder. This is the traditional notion that a lawyer's function is to advocate the position that his client favors and to allow the client to make the ultimate decisions that must be made in litigation. ${ }^{11}$

Thus the lawyer is confronted with two alternative roles as models for his conduct; they might be termed the "best interest" role and the adversary or advocacy role. ${ }^{12}$ Each role has its adherents. Faced with these conflicting alternatives, the commitment lawyer must search for a guide to help him choose which role to adopt.

\section{Possible Sources of Guidance}

\section{A. The Statutes}

The attorney looking for guidelines as to which role to choose can search the statutes requiring his presence in vain for even a clue. Although some statutes assign certain specific tasks to the respondent's representative, these tasks relate to the acquisition of knowledge rather than the issue of role. ${ }^{13}$ By and large, the statutes simply call for the appointment of counsel or a guardian ad litem without elaborating upon the role to be played. ${ }^{14}$

\section{B. The Code of Professional Responsibility}

The newly adopted Code of Professional Responsibility is likewise lacking in substantive guidance. ${ }^{15}$ Canon 7 dictates that "a lawyer

11. For reports of counsel taking an adversary posture in civil commitment proceedings, see Gupta, supra note 2; Andalman and Chambers, supra note 10, at 60-63.

12. Uncertainty about the proper role for counsel is reflected in the growing body of literature which deals with this question. See Litwack, The Role of Counsel in Civil Commitment Proceedings: Emerging Problems, 62 CAL,1F. L. REv. 816 (1974); Cohen, supra note 10; S. Brakel \& R. Rock, supra note 1 , at 55, 62; R. JANorAul, Problems IN Hospitalizing the Mentally Ill (ABA Foundation Research Memorandum Series No. 31, 1962); R. Rock, M. JAcobson \& R. JANopauL, supra note 10, at 157-60; Andalman \& Chambers, supra note 10, at 46-54; Blinick, Mental Disability, Legal Ethics, and Professional Responsibility, 33 ALB. L. REv. 92 (1968); Golten, Role of Defense Counsel in the Criminal Commitment Process, 10 AM. CrIM. L. Rev. 385, 414-17 (1972); Developments in the Law, supra note 1, at 1288.91; Symposium-Is Counsel Needed at Commitment Hearings?, 23 LEGAL AID BRIEF CASE 13 (1964); Comment, The Expanding Role of the Lawyer and the Court in Securing Psychiatric Treatment for Patients Confined Pursuant to Civil Commitment Procedures, 6 Hous. L. REv. 519, 531-32 (1969). In addition, many articles written about the civil commitment process of particular states often briefly discuss the problem. See, e.g., Dix, supra note 10, at 33; Wexler, Scoville, et al., supra note 10, at 56.59; Note, Involuntary Hospitalization of the Mentally Ill Under Florida's Baker Act: Procedural Due Process and the Role of the Attorney, 26 U. OF FLA. L. Rev. 508 (1974).

13. See, e.g., Colo. REv. STAT. ANN. \$ 71-1-8(2,3) (1963).

14. See, e.g, D.C. Cone $\$ 21-543$ (1973) (counsel); N. CAR. GeN. STAT. $\$ 122-58.6$ (1973) (counscl); Colo. Rev. STAT. ANN. $\$ 71-1-8(1)$ (1963) (guardian ad litem).

15. American Bar Association, Code of Professional Responsibility and Judicial CoNDuCT (1970). 
should represent a client zealously within the bounds of the law."1n Ethical Considerations (EC) 7-11 and 7-12, although touching upon the responsibilities of the attorney dealing with a client who is somehow deficient, fail to make explicit the nature of those responsibilities. All EC 7-11 states is that the lawyer's responsibilities "may vary according to the intelligence, experience, mental condition or age of a client, ... . or the nature of a particular proceeding. Examples include the representation of . . . an incompetent." 17 EC 7-12 adds only that the lawyer may at times "be compelled in court proceedings to make decisions on behalf of the client ..." and that in such instances the lawyer should "consider all circumstances" and act to "safeguard and advance the interests of his client."18

By failing to differentiate among various circumstances under which a lawyer is confronted with the problem of handling a less-than-competent client" and through the use of such vague language as "safeguard and advance the interests of his client," the Code offers little guidance for the representative in a commitment proceeding. Since the very matter in controversy at the hearing is the mental condition of the client, is it the role of the lawyer in effect to prejudge the question and shape his role accordingly? Do decisions to be made on behalf of the client "in court proceedings" include the fundamental decision not to articulate the client's spoken desires to be free from detention, or do they merely refer to tactical decisions? How does the attorney go about ascertaining the "interests" of the client?

\section{Counsel in Juvenile Commitment Proceedings}

Another potential source of guidance for the attorney lies in the role assumed by counsel in juvenile commitment proceedings, for the

16. Id. at $31 \mathrm{C}$.

17. Id. at $33 \mathrm{C}$.

18. Id. at 33C. EC 7-12 states in relevant part:

Any mental or physical condition of a client that renders him incapable of making a considered judgment on his own behalf casts additional responsibilities upon his lawyer. Where an incompetent is acting through a guardian or other legal representative, a lawyer must look to such representative for those decisions which are normally the prerogative of the client to make. If a client under disability has no legal representative, his lawyer may be compelled in court proceedings to make decisions on behalf of the client. If the client is capable of understanding the matter in question or of contributing to the advancement of his interests, regardless of whether he is legally disqualified from performing certain acts, the lawyer should obtain from him all possible aid. If the disability of a client and the lack of a legal representative compel the lawyer to make decisions for his client, the lawyer should consider all circumstances then prevailing and act with care to safeguard and advance the inId.

19. Consider, for example, the different responsibilities of a lawyer dealing with (a) a client who wants to sell his house for $\$ 25$, (b) a client who wants to alter his will, (c) a client threatened by commitment. 
policies underlying the processes for the commitment of juveniles and the mentally ill, and the manner in which the two systems have come to affect those committed, show similarities in many respects. ${ }^{20}$ Gault and Winship, together with McKeiver $v$. Pennsylvania, ${ }^{21}$ mark the Supreme Court's-major discussions of the due process protections to be afforded a youth in the juvenile commitment process. The Court in Gault, speaking through Justice Fortas, noted that the juvenile system had failed to produce the desired results, that abuses were frequent, and that the child faced both a deprivation of liberty and the stigma attached to being labeled a "juvenile delinquent."22 It concluded that the child needs "the assistance of counsel to cope with the problems of law, to make skilled inquiry into the facts, to insist upon regularity of the proceedings and to ascertain whether he has a defense and to prepare and submit it."23

Justice Fortas also noted that, although injecting lawyers into the process would make the proceedings adversary, this was desirable in part: "The juvenile courts deal with cases in which facts are disputed and in which, therefore, rules of evidence, confrontation of witnesses, and other adversary procedures are called for." 24 The Court was quick to point out, however, that these constitutional requirements would not eliminate all the beneficial features of the informal procedure envisioned by its creators. ${ }^{25}$

20. Both systems were designed not to provide a means to punish those falling within their respective jurisdictions but to help them. In neither system was an adversity of interests between the state and the respondent assumed to exist. Rather, no matter what the final disposition of a particular case, the outcome had to be, in theory, favorable to the respondent, for all concerned sought only to act in his best interests. Also, in neither system was the respondent presumed to be capable of making a mature, reasoned determination of what was in his own best interests.

21. 403 U.S. 528 (1971).

22. In re Gault, 387 U.S. $1,15,17$ (1967). Commitment under either system has proven to have adverse effects upon the respondent in these two respects. See note 7 supra.

For examples of the use courts have made of Gault and Winship in civil commitment cases, see, e.g., McNeil v. Director, Patuxent Institution, 407 U.S. 245, 257 (1972) (Douglas, $\mathrm{J}$, concurring); cases cited in note 7 supra.

23. 387 U.S. at 36. The Court also held that other procedural safeguards-the right to adequate and timely notice, the right to confrontation of witnesses, and the privilege against self-incrimination-were applicable.

24. Id. at 39 n.65, quoting RePORT BY THE PRESIDENT's COMMISSION ON LAw ENFORCEment and the Adinistration of Justice, "The Challenge of Crime in a Free Society" 86.87 (1967).

25. Thus, the separate processing of juveniles and adults, the secrecy of the records and the prohibition against disqualification from civil service employment could continue. The operation of other aspects envisioned by the system's originators, such as the maintenance of a nonadversary atmosphere, has clearly been destroyed by the introduction of lawyers into the proceedings. Had the system operated in practice as it was meant to in theory, however, it is far from certain that the court would have decided as it did. Confronted as it was by the widespread stigmatization of youths and their incarceration in prisons masquerading as "homes," the Court wisely chose to respond to the realities of the situation and not to an idealized vision. For a discussion of the assumptions and goals of such a nonadversary system, see Griffiths, Ideology in Criminal Procedure or $A$ Third 'Model' of the Criminal Process, 79 YALE L.J. 359 (1970). 
In $M c K e$ iver v. Pennsylvania, ${ }^{26}$ Justice Blackmun, writing the plurality opinion, held that jury trials were not constitutionally required in juvenile court hearings. Holding that the applicable due process standard was fundamental fairness, the opinion noted that Gault and Winship represented efforts to ensure fairness in factfinding. ${ }^{27}$ Since the imposition of a jury trial would add little, if anything, to the factfinding capability of the court, and since it raised the possibility that the proceeding would be made into a full scale adversary proceeding, thus ending the prospects of "intimate," "informal," and "protective" proceedings, the plaintiff's contentions were rejected. Thus the Court has chosen to view the Due Process Clause as requiring, in the words of a concurring Justice, "not a particular procedure, but only a result: . . . fundamental fairness ... [in] factfinding." "2s While these decisions may appear to call for an advocate's role, debate still persists as to the proper role for counsel in juvenile proceedings. Unanimous agreement is lacking that the lawyer is always to serve as advocate in behalf of the expressed wishes of the client. In Miller $v$. Quatsoe, ${ }^{29}$ for example, the court could state:

$[\mathrm{U}]$ nlike the criminal attorney, the juvenile lawyer, as the name suggests, is representing a child. He cannot, as the adult criminal lawyer perhaps can, rely on the immature judgment of his client. ${ }^{30}$

Similarly, scholarly debate over counsel's role in juvenile court proceedings has remained lively even after the three Supreme Court rulings. $^{31}$

26. 403 U.S. 528 (1971).

27. Id. at 543 .

28. Id. at 554 (Brennan, J., concurring).

29. 332 F. Supp. 1269 (E.D. Wis. 1971). Conlra, People in the Interest of M.B., 513 P.2d 230 (Colo. App. 1973) (grants to youths in delinquency hearings the same constitutional protections as are afforded adults in criminal cases).

30. 332 F. Supp. at 1275 .

31. Articles urging a best interest role upon counsel in juvenile proceedings include Isaacs, The Role of the Lawyer in Representing Minors in the New Family Court, 12 Buffalo L. REv. 501 (1963); Kay \& Segal, The Role of the Attorney in Juvenile Court Proceedings: $A$ Non-Polar Approach, $6 \mathrm{I}$ GEO. L.J. 1401 (1973). For articles which advocate an adversary approach, see Chapman, The Lawyer in Juvenile Court: 'A Gulliver Among Lilliputians.' 10 W. ONT. L. REv. 88 (1971); MicMillan \& McMurtry, The Role of the Defense Lawyer in the Juvenile Court-Advocate or Social Worker?, 14 Sr. Lours U.L.J. 561 (1970); Wizner, The Child and the State: Adversaries in the Juvenile Justice System, 4 Colum. Human Rights L. Rev. 389 (1972). See generally Ferster, Courtless, \& Snethen, The Juvenile Justice System: In Search of the Role of Counsel, 39 Fordhax L. REv. 375 (1971); Handler, The Juvenile Court and the Adversary System: Problems of Function and Form, 1965 Wis. L. REv. 7 (1965); Note, The Need for Counsel in the Juvenile Justice System: Due Process Overdue, 1974 UTah L. Rev. 333, 374-77 (1974). For a discussion of the reaction of juvenile court personnel to Gault, see W. Stapleton \& L. Teiteldaum, IN DEFENSE OF YOUTH $32-37$ (1972). 


\section{Cases Involving Claims of Ineffective Assistance of Counsel and Failure to Provide Counsel}

Yet a fourth potential source of guidance for the lawyer lies in lower court rulings on claims of ineffective assistance of counsel and failure to provide counsel raised by civilly committed persons on appeal or in habeas corpus petitions. Unhappily for the lawyer, however, the decisions are marked by confusion and a lack of uniformity.

In Prochaska v. Brinegar, ${ }^{32}$ the Iowa supreme court rejected a claim of ineffective counsel. Although counsel had failed to file an appeal from the decision to commit the appellant, the court presumed that counsel had "acted for the best interest of the client." This position followed logically from the court's view that the appellant was being detained "for his own protection and welfare as well as for the benefit of society" and that, therefore, no loss of liberty was involved..$^{33}$

The Court of Appeals for the District of Columbia Circuit also rejected an argument charging a denial of effective assistance of counsel in In re Basso, ${ }^{34}$ without shedding much light on the proper role of counsel. The court commented that counsel, in reporting that his client needed treatment, did "what any responsible and competent lawyer would have done" and that, had he done otherwise, he would have rendered his client "a distinct disservice." 35 While thus apparently endorsing the best interest role for counsel, the court went on to equate the guardian ad litem in this case with a lawyer in criminal cases who believes his client guilty, a surprising and almost surely inappropriate analogy. ${ }^{36}$ Thus, the best that can be said for the Basso opinion is that it demonstrates the confusion that exists in this area.

More recently, a few courts have indicated that the lawyer must act as an advocate for his client's expressed desires. In Lessard $v$. Schmidt ${ }^{37}$ a three-judge court in Wisconsin undertook to decide

32. 251 Iowa 834,102 N.W.2d 870 (1960).

33. Id. at 838,102 N.T. $2 \mathrm{~d}$ at 872 .

34. 299 F.2d 933 (D.C. Cir. 1962).

35. Id. at 935. See In $r e$ Ballay, 482 F.2d 648, 649 (D.C. Cir. 1973) (dictum) (speaking of the due process guarantees that are required in a commitment hearing: "[T]he process accorded in any adversary proceeding reflects the interests at stake."); Lake v. Cameron, 364 F.2d 657, 661 (D.C. Cir. 1966) (dictum) (Bazelon, C.J.) (proceedings "involving the care and treatment of the mentally ill are not strictly adversary proccedings"). See generally Mazza v. Pechacek, 233 F.2d 666 (D.C. Cir. 1956) (Judge (now Chief Justice) Burger rejected an effectiveness of counsel argument by a woman whose appointed guardian ad litem refused to argue her position in a conservatorship procceding brought against her by one of her children); Hawkyard v. People, 115 Colo. 35, 169 P.2d 178 (1946) (guardian ad litem not required to notify the defendant in a lunacy proceeding of his right to a jury trial).

36. See p. 1550 infra.

37. 349 F. Supp. 1078 (E.D. Wis. 1972). 
whether the appointment of a guardian ad litem fulfilled the requirement of appointed counsel, held to be constitutionally mandated earlier in the opinion. The court flatly concluded that guardians and counsel occupy distinct roles and that the appointment of only a guardian ad litem failed to satisfy due process requirements. ${ }^{38}$

Thus the lawyer who turns for guidance to the case law concerning ineffective assistance of counsel in the civil commitment context is once again confronted with conflicting opinions as to his proper role.

\section{E. Summary}

It can be seen that no consensus has emerged as to what role counsel should assume when representing a client in the civil commitment process. Numerous adherents of both the best interest and adversary roles are found among the commitment bar. Legislators have not attempted to prescribe a particular role. The Code of Professional Responsibility is riddled with ambiguity. Opinion is deeply split in the courts and among the commentators. As more and more courts recognize that respondents in the civil commitment process must be afforded the right to counsel, however, the need to reach consensus on counsel's proper role becomes imperative. In Part II an attempt will be made to construct a theoretical framework in which the role of counsel can be properly considered.

\section{The Theoretical Framework}

Judge Learned Hand once wrote that our system of criminal procedure "has been always haunted by the ghost of the innocent man convicted." 39 Such a fear has never plagued our civil commitment process. Indeed, it may fairly be said that the civil commitment process

38. Id. at 1097-99. Several state courts have recently arrived at similar conclusions. E.g., Quesnell v. State, 83 Wash. 2d 224, 517 P.2d 568 (1974) (respondent was entitled to an advocate's representation, guardian ad litem prohibited from waiving any of his client's fundamental rights, including the right to a jury trial, without the client's consent). See State ex rel. Hawks v. Lazaro, 202 S.E.2d 109 (W. Va. 1974).

In People ex rel. Rogers v. Stanley, 17 N.Y.2d 256, 217 N.E.2d 636 (1966), Judge Bergan dissented from the majority holding that the right to counsel should be extended to those trying to obtain release from civil commitment. He reasoned that counsel's role would have to be that of an advocate, and that too many mentally ill persons would therefore possibly be done a disservice if the right to counsel was extended to them.

Although the cases in this section which opt for the best interest role are all pre-Gault while those endorsing the adversary model are all post-Gault, this should not be taken as an indication that the question has been resolved. One need only examine the literature cited in note 12 supra and descriptive reports of the conduct of counsel at civil commitment hearings, note 83 infra, to realize that the issue is far from settled.

39. United States v. Garsson, 291 F. 646, 649 (S.D.N.Y. 1923). 
has been long haunted by the ghost of the person in need set free. The spectre of depriving a mentally. ${ }^{\text {ill }}$ person of the treatment he desperately needs and sending him out into the world where he will do harm to himself or others has diverted our attention from (or supplied us with a rationale for ignoring) the interference with the liberty of others which such a system works. The lawyer's role must be articulated as an integral part of a system in which the benefits of its primary goal (providing treatment to those who need it) are balanced against its possible encroachment upon the freedom of those not in need of treatment.

The state's ability to commit the mentally ill is grounded in two powers of the state: its police power and its authority to act as parens patriae. ${ }^{40} \mathrm{~A}$ mentally ill person may be committed under the state's police power if he is dangerous to others or in need of treatment for the welfare of others. ${ }^{41}$ Under the parens patriae justification, the mentally ill individual may be committed if he is dangerous to himself or in need of treatment for his own welfare. Commitment statutes generally fail to distinguish between these two rationales and identical procedural rights are accorded to one who is subject to commitment under the police power model as under the parens patriae model. While it is recognized that elements of both often enter into the decision to institute commitment proceedings, it is analytically helpful to discuss them separately.

\section{A. Commitment Under the Police Power}

In a civil commitment based on the police power of the state, justifying a role for counsel different from that in the criminal process is most difficult. At many points, the line between the power of the state to commit the mentally ill who are dangerous to others and its power to incarcerate criminals is blurred beyond recognition. ${ }^{42}$ For commitment under the police power, mental illness is a necessary but not sufficient condition. Dangerousness to others must also be found. This indicates that the state's major interest in invoking its police power is to protect the public. Central to the commitment theory here

40. See, e.g., Developments in the Law, supra note I, at 1207-23.

41. For an example of a statute explicitly requiring a finding of dangerousness, see N.C. GEN. STAT. $\$ 122-58.6$ (Supp. 1974). For a statute utilizing the "welfare" standard, see CoNN. GEN. STAT. $\$ \S 17-176,17-178$ (1972). For a breakdown of the statutes for all 50 states and the District of Columbia, see Developments in the Law, supra note 1, at 120304 nn.11-14.

42. For a discussion comparing the two processes, see In re Ballay, 482 F.2d 648, 656-58 (D.C. Cir. 1973). 
is the image of one who is mentally ill erupting without warning and committing a violent act. That individual is brought into the system not so much that he may be able to benefit from treatment, but that others might not be harmed. ${ }^{43}$ In this respect, then, the criminal and civil commitment processes both function to remove from society those deemed harmful to others.

Another possible similarity deserves to be explored. The criminal justice system is designed to serve functions other than removing from the community those persons deemed harmful to society. The rehabilitative ideal has an established position in our approach to criminal justice. ${ }^{4 \pm}$ To the extent that it expresses the notion that the criminal can be "treated" for his criminal behavior, the gap between the two systems narrows yet further. Certain forces are perceived as impelling the criminal to his act, forces which can be altered in the institutional setting so as to rehabilitate the criminal. Similarly, the civil commitment system seeks to remove from society those persons who have committed, or are expected to commit, harmful behavior, with the belief that their behavior can be altered through treatment. ${ }^{45}$ Thus far no reason appears that explains why the role counsel plays in the commitment proceeding should be different from the adversary role which he assumes in the criminal proceeding (even if he believes his client to be guilty)..$^{46}$ In both, the state acts not with the best interest of the respondent in mind, but to promote the greater good of society.

The criminal justice system also serves deterrent and retributive functions. These functions will only be served, however, if those individuals committing criminal acts are apprehended and convicted. The deterrent effect of the threat of prison will be slight if one per-

43. The idea that the mentally ill are more dangerous than other segments of the population is the subject of a growing body of empirical research, much of it conflicting. See, Rappeport \& Lassen, Dangerousness-Arrest Rate Comparisons of Discharged Palients and the General Population, 121 AM. J. PsYchiatry 776 (1965) and studies cited therein.

44. See, e.g., F. Allen, The Borderland of Criminal Justice 25-42 (1969).

45. Note that to the extent to which rehabilitation in the criminal correctional system is effective, the often expressed notion is undermined that the lawyer, in trying to "get his client off," is acting in his client's best interests.

46. That an attorney owes a client whom he believes to be guilty a full defense is widely accepted. See, e.g., Orkin, Defence of One Known to be Guilty, 1 Crim. L. Q. 170 (1958); M. Schwartz, Cases and Materials on Professional Responsibility and THE AdMinistration of Criminal Justice 74-87 (1961); American Bar Association, Standards Relating to the Prosecution Function and the Defense Function (Tentative Draft 1970); New York County Criminal Courts Bar Association Code f 3. This is not to say that the legal profession is of one mind as to the boundaries of ethical behavior in defending a client. See, e.g., Bress, Professional Ethics in Criminal Trials: $A$ View of Dcfense Counsel's Responsibility, 64 Mrch. L. Rev. 1493 (1966); Freedman, Professional Responsibility of the Criminal Defense Lawyer: The Three Hardest Questions, 64 MIcry. L. REv. 1469 (1966); Noonan, The Purposes of Advocacy and the Limits of Confidentialily, 64 MICH. L. REv. 1485 (1966). The consensus within the profession, however, is clearly that a guilty person deserves as full a defense as his lawyer can provide him. 
ceives but a small possibility of incarceration; and the retributive function comes into play only upon conviction. Erroneous acquittals, then, will render the criminal justice system less effective. As deterrence and retribution are of far less significance in the civil commitment scheme, both in theory and practice, the deleterious effect of erroneous releases will be less marked there than in the criminal justice system. Thus, under the police power model, society should be no more concerned if a mentally ill person escapes commitment due to adversarial lawyering. ${ }^{47}$

If society, however, were to view the improper incarceration of one in the criminal system as more egregious an error than a mistaken mental hospitalization, it would be less concerned if a person were mistakenly committed than mistakenly convicted. This view would spring from the perception that prison exists to punish, while civil commitment is a process existing only for the good of the patient. Neglected in such an argument, however, is that the fundamental penalty paid by convicted criminals has its source not in the actual routine inside the prison, but in their loss of personal liberty, ${ }^{48}$ a loss endured by those committed to mental hospitals no less than by those imprisoned. ${ }^{40}$ Thus, even if one were to receive excellent care in a hospital, the erroneously committed person suffers no less a loss of liberty than the unjustly convicted individual. Since improper incarceration is just as grievous a mistake in one system as in the other, ${ }^{50}$ the adversarial role is just as appropriate for counsel in the civil as in the criminal commitment system.

Psychiatrists often argue, however, that hearings, especially adversary hearings, should not be held. They contend that such hearings are anti-therapeutic for the respondent. ${ }^{51}$ Such a generalization must, how-

47. To the extent that society felt itself in need of protection from the uncommitted mentally ill more acutely than it does from acquitted criminals, this argument would be vitiated. One would encounter great difficulty, however, in attempting to argue persuasively that the importance the public places upon being safe from mentally ill persons is so overriding so as to outweigh not only its fear of unconvicted criminals, but also the deterrent and retributive functions of the criminal system as well.

48. See American Friends Service Commitree, Struggle for Justice 33 (1971). See generally Speiser v. Randall, 357 U.S. 513 , 525 (1958) (at stake in criminal trial is defendant's liberty, an interest of transcending value).

49. In re Ballay, 482 F.2d 648, 668 (D.C. Cir. 1973).

50. The reality of the conditions in most mental hospitals, which often provide little more than a facility in which to warehouse the mentally ill, only serves to reinforce this conclusion. See, e.g., Wyatt v. Aderholt, 503 F.2d 1305, 1310.12 (5th Cir. 1974); New York State Ass'n for Retarded Children, Inc. v. Rockefeller, 357 F. Supp. 752, 756 (E.D.N.Y. 1973). So too does the fact that most statutes provide, either explicitly or implicitly, that involuntary civil commitments, unlike most criminal commitments, are to be of indefinite duration.

51. See, e.g., M. Gutraracher \& H. Wemofen, Psychiatry and the Law 298 (1952); Guttmacher, Problems Faced By the Impartial Expert IVitness in Court: The Anerican View, 34 TEMP. L.Q. 369,377 (1961). 
ever, be taken with such a large grain of salt that it simply cannot be swallowed whole. Given the wide range of mental illnesses with which one can be afflicted, and the complexities and dynamics of each individual's case, it is only remotely possible that hearings are anti-therapeutic for all patients. That they do harm to even a substantial minority has never been established. Indeed, for many patients who believe they are being unjustly kept, an adversary proceeding could well have a legitimating effect and thus prove to be quite therapeutic. ${ }^{52}$ As no solid evidence has yet been produced in support of the psychiatrists' contentions, adversary hearings should not be foregone. ${ }^{53}$

In sum, the lawyer representing an individual in a commitment hearing based on the state's police power should assume an adversary stance. Nothing argues persuasively for counsel's assuming a role any different from the advocate's role taken in the criminal process. ${ }^{54}$

\section{B. Commitment Under the Parens Patriae Model}

Determining the proper role for counsel under the parens patriae rationale for civil commitment presents greater analytical difficulties. Most analysis which recommends that the civil commitment attorney take an adversary position simply contends that, as the client is being threatened with a deprivation of liberty, he faces the same disposition that he would in a criminal case..$^{55}$ Thus, even if the proceeding is denominated "civil," the client is still owed an adversary hearing. This line of argument fails to confront the essential difference between the civil commitment proceeding and a criminal case; that is, if the client is acquitted in a criminal case, he benefits, while if he gains release in the commitment proceeding, in some instances he will be deprived of needed though unwanted treatment. ${ }^{50}$

52. See Developments in the Law, supra note 1, at 1285. See also In re Gault, 387 U.S. 1 , 38 n.65 (1967) (suggests that counsel's presence in juvenile proceedings may be therapeutic).

53. This is not to say that adversary hearings will never affect adversely a mentally ill individual. Hopes may be raised only to be dashed, and persecution complexes may be fed, to recite but a portion of the psychiatrists' anti-hearing litany. Such harm, however, likely to be restricted to a limited number of instances, is far outweighed by the harm that would be incurred by proscribing such hearings.

54. Other benefits which were envisioned by its originators to flow from the informal, nonadversary procedure need not necessarily be sacrificed. Court records may still be kept confidential and civil disabilities need not attach to an adjudication of commitment. See note 65 infra. Nor must the respondent be required to attend his hearing if he knowingly waives his right to attend. The question of what would constitute a knowing waiver is, of course, the proper subject for tomes of scholarly writings and will not be dealt with here. See Johnson v. Zerbst, 304 U.S. 458 (1938).

55. See cases cited in notes 37,38 supra; articles cited in note 12 supra.

56. So as to pose the problem in its most difficult form, it is here assumed both that no rehabilitative benefits flow from criminal commitments and that those who are civilly committed receive beneficial treatment. 
It must be emphasized that no adjudicative system that we can design will be without its defects. Errors are bound to be made and their costs will inevitably fall upon some members of society individually and upon society as a whole. In the criminal justice system, for example, we can be certain that some of the proverbial 10 guilty men who are acquitted and set free so that one innocent man will not unjustly be convicted ${ }^{57}$ are going to return to the community and commit other crimes. The harm inflicted by such acts upon the victims represents a cost that must be weighed against the harm of an unjust conviction. Society has determined that the latter cost outweighs the former. Thus, society is willing to acquit the " 10 guilty men" and absorb the harm they inflict rather than convict one man unjustly.

In the civil commitment system, too, the costs of various mistakes must be identified and weighed against each other. In the parens patriae model, where the focus is not on harm to others, but on the needs of the individual respondent, society as a whole bears no direct cost. ${ }^{58}$ Rather, the cost of mistakes falls upon those who need treatment but who are not committed ("undercommitments") and those who do not need treatment but who are committed ("overcommitments"). The balance that society must strike, then, involves determining how many overcommitments it will tolerate in order to insure that a person in need of treatment does not escape commitment; or, alternatively stated, how many undercommitments society is willing to accept so that one who is not in need of treatment is not mistakenly committed. Although obviously not susceptible to precise analysis, such a comparison is constantly being made. The role of counsel should be formulated as one element of an adjudicatory system designed to achieve whatever balance it is that society determines is proper.

\section{Overcommitments}

Several considerations tend to suggest that, at present, many overcommitments are occurring. We have, of course, no accurate means of determining whether an unacceptable number of people are presently being committed who should not be, since we possess no precise yardstick by which we can objectively measure who truly needs to be committed. The fact is, however, that when lawyers are present at

57. "[T]he law holds that it is better that ten guilty persons escape than one innocent suffer." $4 \mathrm{~W}$. BLACKSTONE, Commentaries *358.

58. Society does, however, bear indirect costs arising from mistaken commitments by dint of the diminished respect for liberty engendered by such mistakes. 
commitment hearings, commitment rates have been significantly reduced. ${ }^{50}$ This suggests that psychiatrists unchecked by opposing counsel seek to commit many who, given the articulated legal standard, ${ }^{\text {BO }}$ should not be committed.

First, when a psychiatrist predicts that a person will not engage in behavior harmful to himself and is mistaken, he will likely learn of his mistake. When a psychiatrist predicts that a person will engage in such harmful behavior, however, the person will likely be confined to a hospital. If he fails to engage in the predicted harmful behavior, his conduct will of course be attributed not to error on the psychiatrist's part, but to the institutional restrictions. Thus the psychiatrist will receive more negative feedback from erroneous predictions of nonharmful behavior than of harmful behavior and will be thus inclined to overpredict rather than underpredict harmful behavior. ${ }^{\circ 1}$

Second, from an institutional perspective, the publicity which erroneous predictions of nonharmful behavior receive leads the institutional psychiatrist to recommend commitment in marginal cases. Quite often a person awaiting a commitment hearing is already being detained at an institution. ${ }^{62}$ Nothing can be more distressing to the superintendent of a hospital than to read newspaper accounts of a suicide or violent crime committed by a patient recently released. Thus, fear of public reaction and consequent political repercussions will also lead the institutional psychiatrist toward overprediction. Finally, once a person is alleged to have mental problems, the psychiatrist tends to interpret his behavior in the framework of a mental illness. ${ }^{63}$

The chances are, then, that large numbers of individuals are being committed who should not be. The cost to these individuals is clear. They are being deprived of the most fundamental of their freedoms, their liberty. The rationale that treatment is being given them does not detract from the harm. These are persons who, the legislatures

59. See note 2 supra.

60. See note 64 infra.

61. Dershowitz, Psychiatry in the Legal Process: A Knife That Cuts Both Ways, 4 Trial, 33 Feb./Mar. 1968 at 29.

62. Involuntary commitment proceedings are frequently instituted following the expiration of the statutory period of detention permitted pursuant to an emergency admission. Detention prior to the hearing also occurs when the individual, a voluntary patient, seeks release from the hospital and the institution decides to press for commitment. Hearings are also conducted in accordance with statutory schemes directing periodic judicial review of each committed patient's case. Finally, hearings are held pursuant to a petition of habeas corpus filed by the patient.

63. See, e.g., Rosenhan, On Being Sane in Insane Places, 179 ScIENce 250 (1973); Kumasaka \& Gupta, Lawyers and Psychiatrists in Court: Issues on Civil Commitment, 32 MD. L. REv. 6, 34 (1972). 
have determined, ${ }^{64}$ should not be committed involuntarily or compelled to undergo treatment. Even if they receive excellent care, they are still being deprived of their liberty unjustly. ${ }^{65}$

The adversary system, premised on the belief that the truth of a controversy is most likely to surface when the two sides confront each other in a courtroom, has traditionally been held to be the method of adjudication most likely to reduce the number of mistaken incarcerations in the criminal system. ${ }^{\text {6 }}$ This should hold true for the cases in the civil commitment area as well. ${ }^{67}$ If so, the civil commitment

64. In states utilizing a dangerousness criterion, it is clear that legislatures meant to preclude the involuntary commitment of those individuals who are mentally ill and who could benefit from treatment, but who present no danger to themselves. Further, it can be argued that implicit within a seemingly lesser standard such as "in need of treatment for one's own welfare" is a dangerousness criterion. See Lessard v. Schmidt, 349 F. Supp. 1078,1093 (E.D. Wis. 1972). Thus even in those latter states not all individuals who would benefit from treatment are properly subject to involuntary commitment.

65. Other legal deprivations may befall the committed individual. Although some states make explicit that an adjudication of commitment does not render an individual legally incompetent, see, e.g., CoNN. GEN. STAT. Rev. $\$ 17-206($ c) (1973), in other jurisdictions commitment may so affect a patient, see, e.g., Colo. Rev. STAT. ANN. \$ 71-1-11 (1963); id. \$71-1-26 (Supp. 1971). Commitment may also bar an individual from a wide variety of professions, see, e.g., Wis. STAT. ANN. \$256.286(1) (1971) (license to practice law); GA. CODE ANN. $\$ 80-106$ (1973) (riverboat pilot's license); and from making a contract, see, e.g., Colo. REv. STAT. ANN. \$ 71-1-21 (1963).

Another consequence of commitment is the stigma which attaches to being deemed mentally ill, often resulting in severe repercussions in a person's later life, in terms of personal relations, employment and educational discrimination, and evaluation of selfesteem.

66. Some empirical work has been done recently in an effort to test the hypothesis that an adversary procedure provides for more accurate factfinding. Lind, Thibaut \& Walker, Discovery and Presentation of Evidence in Adversary and Nonadversary Proceedings, 71 MICH. L. REv. 129 (1973). There, the authors found no significant difference in diligence in seeking information between those "attorneys" assigned to inquisitorial and adversary roles, except when the distribution of facts was unfavorable to the client. Under those circumstances (likely to be the circumstances surrounding commitment hearings in most instances), the "attorneys" to whom the advocate's role had been assigned demonstrated greater diligence in ferreting out facts. Since the best interest model resembles an inquisitorial method of factfinding, these results are applicable to the civil commitment situation.

The same three authors also sought to investigate empirically the comparative effect of the presentation of evidence in adversarial and inquisitorial systems. They found that adversary presentation had its greatest inpact in situations in which the judge or jury were predisposed toward a given outcome, which is likely to be the case at the civil commitment hearing. Thibaut, Walker \& Lind, Adversary Presentation and Bias in Legal Decisionmaking, 86 HARv. L. REv. 386 (1972). See generally Barrett, The Adversary System and the Ethics of Advocacy, 37 Notre Dame LAw. 479 (1962); F. James, Civil Procedure 3-8 (1965); cf. J. Frank, Courts on Trial 80-107 (1950).

67. The wide use of psychiatrists as experts in various legal forums has sparked debate in regard to the efficacy of the adversarial process in presenting accurately such expert testimony. Psychiatrists contend that psychiatric material is the most difficult of all medical knowledge to present accurately from the witness stand and that crossexamination unfairly distorts the testimony given. Guttmacher, supra note 51, at 370 . See generally Van Dusen, The Impartial Medical Expert System: The Judicial Point of I'icw, 34 TeMr. L.Q. 386 (1961); Willis, Psychiatric Testimony, Trial Gamesmanship And the Defense of Insanity, 5 SAN DIEGo L. REv. 32 (1968). The general feeling among this group is that courts should appoint impartial experts who will report to the court and not be subject to adversarial inquiry.

On the other hand, some argue that use of an impartial expert will necessarily result in presentation of a biased view, especially in a field such as psychiatry, where strong 
lawyer can best assure that persons will not be mistakenly committed by assuming an adversarial rather than a best interest role.

\section{Undercommitments}

Proponents of the best interest role, however, fear that placing the lawyer in the role of advocate will concomitantly result in a large increase in releases for individuals who should be treated. The easiest way to calm this fear would be to reiterate that our legal system is based on the notion that the adversary system is best able to ferret out the truth, and thus the lawyer's adversarial role should not increase the rate of undercommitments. Behind this fear, however, must lie the idea that the adversary system is not the most accurate means of arriving at the truth. ${ }^{\text {s }}$ Were this so, and were the benefits gained through the decrease in overcommitments not worth the cost of the increase in undercommitments, the adversary role might be inappropriate for the civil commitment lawyer.

At first glance, the prospect of a jump in the number of undercommitments appears frighteningly real, since currently in many jurisdictions the complainant is often not represented by counsel. ${ }^{09}$ The dan-

disagreement persists over many basic questions. See, e.g., Polsky, Expert Testimony: Problems in Jurisprudence, 34 TEMP. L.Q. 357 (1961). See generally the literature on the adversary process cited in note 66 supra.

The danger of bias is great enough to render the latter the more persuasive view. In addition, the court-appointed impartial witness approach uses a hatchet where a scalpel would do. The solution to the problem of distortion of psychiatric testimony on crossexamination lies in proper regulation of cross-examination, not in precluding contrary views from consideration. Thus, for example, one might want to bar counsel from inquiring of a psychiatrist about particular details of a psychiatric test employcd and restrict him to probing the expert witness about the reliability of the test. For an example of the type of questioning which sours psychiatrists on the adversary procedure, see United States v. McNeil, 434 F.2d 502, 504 (D.C. Cir. 1970) (Bazelon, C.J., concurring).

68. This is not, however, necessarily incompatible with our preference for the adversary system in criminal cases. If the adversary system is more accurate than the inquisitorial system in avoiding mistaken incarceration, but less accurate in avoiding mistaken acquittals or releases, given our societal preference for mistaken acquittals over incarcerations, we might still deem the adversary system the better one. For example, suppose that out of every 10 cases, an inquisitorial system produced the correct verdict in nine, and that the one incorrect verdict results in an innocent man's conviction. Further suppose that out of every ten cases, the adversary system produces only seven correct results, but that the three mistakes are all acquittals of guilty individuals. The inquisitorial system would produce more accurate results (90 percent to 70 percent) than the adversary system, but would be considered the inferior mode of adjudication. Given that society may wish to strike a different balance between mistaken incarcerations and releases in the civil commitment system than it does in the criminal justice system, however, it cannot simply be assumed that the adversary system is the preferred mode of adjudication.

69. Cohen reports that no attorney for the complainant is present at commitment hearings in Texas. Cohen, supra note 10, at 448 . In only a few of the 55 hearings monitored at Bellevue by Kumasaka and Gupta was counsel for complainant in attendance. Kumasaka \& Gupta, supra note 63, at 8. In one Arizona county the judge was unaware that the state (the usual complainant) was permitted representation, so accustomed was he to its absence. Wexler \& Scoville, supra note 10, at 51. See Johnson, Due 
ger exists, therefore, that the system lacks an adequate counterweight to the lawyer's proposed adversary role and that the balance will be tipped too far in the respondent's direction..$^{70}$ Legislatures, of course, can always provide that counterweight by requiring counsel for the complainant to be present at the hearing. That the lack of committing counsel will always work against commitment, however, is not clear. When the judge is forced by the absence of counsel for the complainant to look himself for holes in the respondent's case and to develop the case for commitment, he must identify himself with the complaining party. He must subsequently try to revert to his position of neutrality, and in such a role is required "to view with distrust the fruits of this identification and be ready to reject the products of his own best mental efforts."71 The difficulty of this return to a neutral stance suggests that the judge, temporarily filling the role of complainant's counsel, may at times provide more than an adequate counterweight to the unopposed advocate.

A more important counterweight to the lack of counsel for the complainant, however, is the difficulty which counsel for the respondent faces in attempting to win a civil commitment case. A commitment hearing generally commences only when some psychiatrist recommends that the respondent be confined. ${ }^{72}$ Although those psychiatrists who testify in favor of commitment often do so without the support of counsel, the deference which is normally accorded their opinions by the factfinder ensures that premium value will be placed upon their testimony. ${ }^{73}$ Thus, respondent's adversarial lawyer will be hard

Process in Involuntary Civil Commitment and Incompetency Adjudication Proceedings: Where Does Colorado Stand? 46 DEN. L.J. 516, 545, 548 (1969); see generally Pfrender, Probate Court Attitudes Toward Involuntary Hospitalization: A Field Study, 5 J. FAM. L. 139 (1965).

70. This fear was articulated in In re Lang, a juvenile court case where the judge complained that she frequently had to elicit the testimony of the state's witnesses. 44 Misc. 2d 900, 255 N.Y.S.2d 987, 992 (Fam. Ct. 1965).

71. V. Countryman, The Lawyer in Modern Society iii (1962).

72. Most state statutes, for example, require a pre-hearing psychiatric examination. $S$. Brakel \& R. Rock, supra note 1, at 50-51, 70-76. Many states require medical corroboration when the commitment petition is initially filed.

Reluctance among psychiatrists to attend commitment proceedings has been reported. For example, Bruce Ennis claims that in 60 percent of the cases in which a petition for a writ of habeas corpus is filed the patient is discharged, often because the hospital staff wishes to avoid the inconvenience of a hearing. Hearings on Constitutional Rights "of the Mentally Ill Before the Subcomm. on Constitutional Rights of the Senate Comm. on the Judiciary, 91st Cong., 1st \& $2 \mathrm{~d}$ Sess. 289 (1969, 1970). [Hereinafter cited as Hearings.] Accounts of hearings, however, generally note the presence of psychiatrists. At the very least, the certificates filed by the psychiatrists and the medical records of the patient are available to the courts.

73. In the Wenger and Fletcher study, for example, the factfinder disagreed not once with the psychiatrists' opinions in the 81 hearings observed. Wenger \& Fletcher, supra note 2, at 68. See also Wexler, Scoville, et al, supra note 10, at 60; Pfrender, supra note 69 , at 147; $R$. Rock, M. Jacobson, \& $R$. Janopaul, supra note 10 , at $155 ;$ cf. Weihofen, Detruding the Experts, 1973 WASH. U.L.Q. 38 (regarding sanity-insanity determinations). 
pressed to defeat an unrepresented petitioner or overcome the testimony of petitioner's psychiatrist.

At times, however, respondent's lawyer will prevail through crossexamination, investigation of the facts, or his own lay and expert witnesses, and in that case we must consider the likelihood that the winning respondent was actually in need of treatment. This will turn partially upon the extent to which psychiatrists' predictions of harmful behavior are reliable and accurate. ${ }^{i t}$ The greater the reliability and accuracy of psychiatric evaluations, the more limited the likely impact of the lawyer as adversary. His ability to produce doubt in the mind of the factfinder will be reduced. The chances of finding another psychiatrist to testify in favor of his client will be diminished. Even if he does locate a psychiatrist who will so testify, the testimony of the committing psychiatrist may still be given priority by the factfinder. Further, in those cases in which the psychiatrist's prediction of dangerousness to self is linked to past aberrant behavior, the respondent is unlikely to escape commitment.

If, on the other hand, no reliable means exists of assessing the treatment needs of individuals whose commitment is sought, the adversary lawyer is more likely to be able to discredit petitioner's predictions of harmful behavior, find credible experts to testify for the respondent, and thus prevent the respondent's civil commitment. If diagnoses of harmful behavior are in fact not reliable and accurate, the problem of committing many who should be left free in order to ensure the commitment of the one who is in need of treatment resurfaces, and the validity of the legal standards must be questioned. ${ }^{75}$ But society should, in any event, be very hesitant to confine people without the benefit of the necessary tools of prediction.

The entire civil commitment process is premised on the assumption that psychiatrists generally are both accurate and reliable. ${ }^{70}$ Even ac-

74. Reliability signifies the extent to which psychiatrists agree in their diagnoses of a particular individual. Accuracy refers to the correctness of their diagnosis. Obviously, psychiatrists can be quite reliable without being accurate.

75. In Papachristou v. City of Jacksonville, 405 U.S. 156 (1972), the Court declared unconstitutional a vagrancy ordinance which lacked definite standards and thus afforded officials an opportunity for "arbitrary and discriminatory enforcement of the law." Id. at 170. If psychiatric predictions of harmful behavior are unreliable and inaccurate, the standards for commitment are arguably as imprecise as those invalidated in Papachristou.

76. Empirical study of this question has been limited. What has been done, however, suggests that psychiatrists are far from accurate in their predictions of dangerousness. See Ennis \& Litwack, Psychiatry and the Presumption of Expertise: Flipping Coins in the Courtroom, 62 CALIF. L. REv. 693 (1974) and studies cited therein.

If in fact psychiatric evaluations are unreliable, demanding that counsel determine the best interests of his client becomes even more untenable. If experts in the field are unable to agree, on what ground can counsel presume to evaluate his client's needs? 
cepting this assumption, the process is skewed towards overcommitting. ${ }^{77}$ Since the lawyer's ability to effect releases is in large part directly related to the tendency of psychiatrists to overpredict harmful behavior, ${ }^{78}$ and given the obstacles he must hurdle to gain release for his client, it appears that the adversary lawyer's impact will be much greater in reducing overcommitments than in increasing undercommitments when he wins the release of his client. This is not to say that no undercommitments will result from counsel adopting an adversary stance. Human error is inevitable. The point is, however, that fears of greatly increased undercommitments are unfounded. Whatever is currently thought to be a proper balance between overcommitments and undercommitments under the parens patriae model of civil commitment, the adversary role should enhance the presentation of facts and improve decisionmaking in the civil commitment process.

Even if placing the lawyer in an adversary position results in more undercommitments than are anticipated by the preceding paragraphs, or if the slight anticipated increase in undercommitments is itself socially unacceptable, means other than removing the lawyer from his traditional role as advocate can be employed to rectify the balance. Evidentiary rules are used as a means of striking the proper balance between mistaken acquittals and convictions in the criminal process. ${ }^{79}$ We require proof beyond a reasonable doubt to convict; we do not require absolute certainty. We allow some hearsay evidence into court, though we believe it to be less reliable than live testimony by the declarant. We allow inferences to be drawn from certain sets of facts, knowing that the inference does not inevitably follow from those facts.

77. See p. 1554 supra.

78. If the higher visibility of erroneous predictions of nonviolent behavior drive the psychiatrist toward overpredicting violent behavior, the lawyer will more likely be able to produce contrary expert testimony. By locating a psychiatrist relatively uninvolved in the civil commitment process, thus relatively unexposed to such negative feedback, the lawyer will have found an expert less prone to overpredicting dangerousness. Similarly, the lawyer may search for expert opinions among psychiatrists insulated from the institutional pressures which impel institutional psychiatrists toward recommending commitment where it is not needed. Third, through presentation of lay witnesses and investigation of relevant facts, the lawyer may convince the factfinder, and at times the committing psychiatrist, that the latter's prediction was erroneous. In the Wenger and Fletcher study, for example, the psychiatrists' opinion was followed in every case. In those cases in which lawyers were present, however, the psychiatrist recommended commitment much less frequently. Wenger \& Fletcher, supra note 2, at 68-69. Finally, the lawyer may present alternatives to involuntary commitment, such as available out-patient care, of which the committing psychiatrist had been unaware, and which would have persuaded him not to recommend commitment had he known of them.

79. See In re Winship, 397 U.S. 358, 368-72 (1970) (Harlan J., concurring). 
These same mechanisms that allow for adjusting the balance in the criminal process are available for manipulation in the commitment process. If undercommitments need to be reduced, the burden of proof can be lowered. If society is willing to accept more mistaken detentions in the civil commitment system than in the criminal justice system, a beyond a reasonable doubt standard may be rejected in favor of a clear and convincing evidence or a preponderance of the evidence standard. Alternatively, hearsay evidence can be admitted, or more inferences can be allowed. ${ }^{80}$ Should the legislature conclude that the factfinder needs more information presented in a more orderly fashion, investigatory units can be established as adjuncts to the court. By discretely manipulating the evidentiary rules rather than denying the lawyer his adversary role, society can more effectively implement the balance it seeks to achieve in the civil commitment process.

Thus it has been established that the adversary lawyer's impact will work largely in the direction of reducing overcommitment. While undercommitments may increase, they will likely do so by only a small number. Further, society has available to it other tools by which to "fine tune" the balance between overcommitments and undercommitments achieved through adjudication.

The question remains, however, whether counsel acting according to the dictates of the best interest role would function as effectively as or better than the adversary lawyer and produce results as favored or more favored by society. Several considerations compel the conclusion that he will not.

First, as a practical matter, less incentive exists for a best interest lawyer to solicit expert opinions, probe facts, and seek out alternative dispositions. Faced with the opinion of an apparently competent psychiatrist that his client constitutes a danger to himself if not committed, counsel's natural reaction will often be to nod in agreement and decide that, indeed, his client's best interests demand hospitalization. The tendency to defer to expert judgment and counsel's probable unfamiliarity with the psychiatric jargon with which the opinion will be delivered stand as strong deterrents to the best interest lawyer's deciding to fight commitment. An attorney placed in the role of advocate, however, cannot acquiesce as easily in the psychiatrist's opinion. The incentive will be greater to ferret out facts and opinions in support

80. To some extent such tactics are already being employed. See Legal Aid Agency of the District of Columbia, Practice Manual for Cases Before the Commission on Mien'tal HeALTH, reprinted in Hearings, supra note 72, at 975, 978. The Commission on Mental Health hears commitment cases and makes reports and recommendations to the court. At the Commission's hearings, "there are no rules of evidence and objections are useless." 
of his client's desire for release ${ }^{81}$ and thereby fulfill his adversary role.

Second, the best interest lawyer is effectively insulated from claims of ineffective assistance of counsel. If counsel acts in the best interest role, courts will experience great difficulty separating out those lawyers who have acted in a manner they considered consistent with the best interests of the client from those who have acquiesced in commitment simply as a means of avoiding work.

Third, should a client be committed, the adversary lawyer is more apt to explore possible avenues leading to discharge. Thus mistaken commitments stand the possibility of rectification. Where the best interest lawyer acquiesces in his client's commitment, however, no such possibility of redress exists. ${ }^{82}$

In summary, then, it appears that the lawyer acting in an adversary capacity will work to reduce overcommitments without substantially increasing undercommitments; that more suitable methods than changing counsel's role are available for adjusting the balance between overcommitments and undercommitments; and that the adversary lawyer is more likely to achieve results compatible with societal goals and values than is the lawyer fulfilling the best interest role.

\section{Civil Commitment and the Adversary Lawyer}

That commitment hearings be fair is insufficient; they must appear to be fair as well, both to the public and to the person involved. Justice would have to be downright myopic to see in the pictures painted of commitment hearings in Texas, Los Angeles, San Francisco, Arizona, and elsewhere ${ }^{83}$ any semblance of a fair hearing. Nor could

81. See note 66 supra.

82. Some commentators have urged an adversary role upon counsel except in instances in which his client clearly is in serious need of treatment. See, e.g., Developments in the Law, supra note 1, at 1288-91. Three problems inhere in such a solution. First, it gives to lawyers prone to defer to expert psychiatric opinion license to acquiesce in that opinion merely by independently determining that the client is an extreme case. Second, it provides another layer of insulation between the lawyer and allegations of "ineffective assistance of counsel." If the client is committed and subsequently raises such a claim, the attorney can plead in defense that he had determined this was an extreme case in which the best interest approach was proper. Third, as a practical matter, the lawyer's impact will be slightest in those cases in which the client clearly needs treatment. If it is obvious to the lawyer, it should be obvious to the psychiatrist and factfinder as well. Nothing is gained therefore, by making such an exception to the general rule that counsel should act as adversary.

83. Cohen describes the typical procedure in Texas as one in which one lawyer is appointed by the court to represent all the respondents scheduled for a hearing on a particular afternoon. In one observation, a 75 minute session, 40 clients had hearings and all were committed. The attorney saw not one of them prior to the hearings, even though two had written him. Only two of the 40 were present at their hearings, one of whom protested the proposed commitment. Following, at best, a halfhearted crossexamination of the testifying physicians, he assured the protesting client that she would 
a person so represented help but feel that he was being railroaded into the hospital. Whether the lawyer's efforts as advocate alter the results of a particular hearing or not, they should at least help generate the appearance of fairness, thus adding to the integrity of the commitment process.

Once the adversary nature of the lawyer's role is reestablished in commitment proceedings, his role in operational terms resembles that in ordinary cases. He may serve as elucidator of the law, laying out for his client in objective fashion the legal problems facing him, the consequences of a commitment decision, the likelihood of prevailing at the hearing, and possible alternatives to commitment. The ultimate decision as to whether to challenge the commitment petition must, however, be the client's. If the client expresses a desire to contest the commitment, the lawyer must do all he can to defeat the petition. As in a criminal setting, of course, he may discuss with the patient the possibility of "plea bargaining"; that is, negotiating less restrictive, more desirable alternatives to commitment. Arrangements may be made for his client's voluntary participation in an outpatient program in lieu of commitment, for example, or for trial visits away from the hospital while still under the institution's jurisdiction. Should the commitment decision be unfavorable, counsel must be prepared to take an active role in the dispositional phase, seeking out alternatives to total commitment in the hospital. Again, however, the client must be presented with a range of alternatives and be allowed to choose the one he prefers. Although communication with the respondent may prove troublesome (and in some instances impossible) and the lawyer might never be certain that his client means what he says, he must act upon the expressed desires of his client. It is all the lawyer has to go on. 84

not be in the hospital for more than a few weeks. At this point she acquiesced in her commitment. The attorney's sole tasks in the other 39 hearings consisted of signing a waiver of jury trial form and insuring that the statutory notice requirements had been observed. Cohen, supra note 10, at 428-30.

Nor is this practice restricted to Texas. Such a procedure is reported as being the standard practice in Colorado. Johnson, supra note 69 . Descriptions of hearings in Los Angeles and San Francisco reveal minimal efforts by the participating attorneys. $R$. Rock, M. Jacobson \& R. JANOPAUL, supra note 10, at 152-56; Note, The Need for Reform in the California Civil Commitment Procedure 19 STAN. L. REv. 992, 997 (1967).

In Arizona, the role played by defense attorneys in one county is said to be virtually indistinguishable from the role played by the prosecuting county attorneys in the counties in which the latter appear. The respondents' attorneys are reported to be virtually bringing out the case against their clients in court. Wexler \& Scoville, supra note 10, at 53. See also, Dix, Acute Psychiatric Hospitalization of the Mentally Ill in the Metropolis: An Empirical Study, 1968 Wash. U.L.Q. 485 (1968).

84. In those instances in which communication with the patient is impossible, and he expresses no opinion as to whether he wishes to fight commitment, a question arises as to what stance counsel should take. The best method of resolving the problem is to lay 
Though it is regrettable that relations between the professions of law and psychiatry have been somewhat acrimonious, it is nevertheless the attorney's proper role to challenge diligently the opinion of the committing psychiatrist and present more than a silent defense. If hearings are to be meaningful procedures designed to arrive at fair dispositions based on a full presentation of the facts, the lawyer must act as an adversary. Otherwise, the idea that due process is being accorded the mentally ill individual will stand as little more than pretense. $^{\text {sj }}$

The procedure advocated here may result in what many will deem an unduly harsh course of conduct. The lawyer will often be forced to argue for a disposition that might harm his client. Sometimes he will win. And on occasion a client whose release he has precipitated will harm himself. Many a lawyer's immediate reaction might be that at some point he must drop his lawyerly facade and assert his humanistic values and help that person get treatment. But in that instinctual response, sight is lost of the greater harm that may be done in upsetting a delicately balanced system. Even though it is natural for counsel to think that he can tell when someone needs help, a properly functioning civil commitment system dictates that he remain in his adversary role and leave to others that ultimate decision.

down a rule, either that counsel should fight commitment or acquiesce in it, in all such instances. Admittedly, either way mistakes will be made and counsel will press for an outcome contrary to his client's unexpressed desires, but no other approach seems practicable. As between the two possible rules, the wiser course seem to be the one in which counsel will argue against commitment. Such situations arise relatively infrequently, and as a practical matter if the client is totally unable to communicate counsel will likely have little impact on the outcome. By placing him in the position of arguing against commitment, however, greater incentive will be given counsel to seek out information about his client and the alternatives available to him. Further, as it is generally far easier to get into a hospital than to leave once committed, mistaken releases can be more easily rectified than erroneous commitments.

85. "Procedure at once reflects and creates substantive rights,..." In re Gault, 387 U.S. 1, 70 (1967) (Harlan, J., concurring). 